\title{
ARTERIAL RECONSTRUCTIONS ASSOCIATED WITH THE RESECTION OF MALIGNANT TUMORS.
}

\author{
Kenji Nishinari, Nelson Wolosker, Guilherme Yazbek, Antônio Eduardo Zerati,
} Inês Nobuko Nishimoto, Pedro Puech-Leão

Nishinari K, Wolosker N, Yazbek G, Zerati AE, Nishimoto IN, Puech-Leão P. Arterial reconstructions associated with the resection of malignant tumors. Clinics. 2006;61(4):339-44.

OBJECTIVE: When trunk arteries are affected by malignant neoplasia, and surgical treatment involving tumor and arterial resection is used, the vascular reconstruction must be performed immediately to avoid ischemia in the brain and large tissue masses. The objective of this study was to analyze the results obtained with the treatment of patients with malignant neoplasia who underwent tumor and vascular resection associated with arterial reconstruction. The primary patency of reconstructions, the occurrence arterial complications, and patient survival were assessed.

METHODS: Thirty-six patients with cervical, abdominal, or lower limb neoplasias were followed up. These patients underwent elective operations at Hospital do Câncer A.C. Camargo, São Paulo, between September 1997 and September 2004. They were divided into 3 groups according to tumor location: Cervical (14), lower limbs (13), and Abdomen (9). Thirty-eight arterial reconstructions were performed in these 36 patients.

RESULTS: There were 5 arterial complications: 2 early- and 3 late-stage. The early complications consisted of 1 symptomatic carotid occlusion with sequelae and 1 femoral graft rupture without sequelae. The late-stage complications consisted of 1 symptomatic carotid occlusion, 1 occlusion of an axillary-carotid graft, and 1 occlusion of a branch of the aortobifemoral graft, all without sequelae. There was no difference between the primary arterial patency rates. All the deaths (22) resulted from progression of neoplasic disease.

CONCLUSIONS: Arterial reconstructions associated with resection of malignant neoplasia in cervical, abdominal, or lower limbs can be carried out with low rates of morbidity and mortality. There was no difference in the primary arterial patency rates among the groups studied.

KEYWORDS: Malignant Neoplasia, Vascular Resection, Arterial Reconstruction, Arterial Graft, Vascular Prosthesis.

\section{INTRODUCTION}

Findings of vascular bundles affected by neoplasia are unusual, ${ }^{1,2}$ due to fact that in most cases, diagnosis and treatment take place prior to vascular invasion. When surgical treatment is performed and veins are found to be affected by a tumoral mass, resection and ligation of the stumps is generally well tolerated in regions such as the neck ${ }^{3}$ and the upper limbs, ${ }^{4}$ while reconstruction is recommendable for

Hospital of the Cancer AC Camargo, São Paulo/SP, Brazil.

Email: marken@uol.com.br

Received for publication on March 09, 2006.

Accpted for publication on April 19, 2006. large abdominal vessels ${ }^{5}$ and for the lower limbs. ${ }^{6}$ However, when an arterial resection is required, reconstruction is always necessary ${ }^{7,8,9}$ to reestablish the preoperative condition of the arterial axis and thus avoid ischemia, either in very important tissue (brain) or in large tissue masses (lower limbs) with its disastrous consequences.

Most studies reporting on patients undergoing peripheral arterial reconstructions associated with resection of malignant neoplasia only deal with 1 body segment, such as the neck, ${ }^{10,11}$ lower extremities, ${ }^{12,13}$ abdomen,,${ }^{9,14}$ or upper extremities. ${ }^{15}$ The largest sample in any of these studies is 32 patients. ${ }^{4}$ Few studies ${ }^{16,17,18}$ have reported on reconstructions done in different segments. Such samples present 
greater numbers of cases, although in addition to arterial reconstructions, they also encompass reconstructions of single veins, such as the inferior vena cava and the portal vein.

The present study, which is part of a general survey on surgical correction of arterial pathology from our service ${ }^{19-21}$ had the objective of making a retrospective analysis on the largest sample in the literature, consisting of patients who underwent surgery to resect malignant neoplasia, with concomitant arterial reconstruction. The primary patency of the reconstructions, arterial complications, and survival of these patients were analyzed.

\section{METHODS}

Thirty-six patients (22 men and 14 women) with ages ranging from 15 to 79 years were followed up. These patients presented malignant neoplasia in the cervical, abdominal, or lower limbs and underwent elective surgical treatment at Hospital do Câncer A.C. Camargo, in São Paulo, between September 1997 and September 2004. Their tumor and vascular resections were associated with arterial reconstruction, and these procedures were carried out by the vascular surgery team at the Hospital.

Fourteen patients presented neoplasia in the cervical region, 13 in the lower limbs, and 9 in the abdominal region. The patients were divided into 3 groups according to the location of the arterial reconstruction, which primarily was determined by the location of the tumor as follows: Cervical (C), Abdomen (A), and Extremity (E).

Only 13 of the patients were undergoing treatment for the first time. Among the previous types of treatment for the neoplasia (single or combined), 18 patients had already undergone surgical treatment, 17 had had radiotherapy, and 14 chemotherapy.

Patients were initially assessed by the oncological surgeon. The suspicion of vascular involvement was based on image exams such as computerized tomography, or nuclear magnetic resonance. Diagnosis was confirmed when the image revealed the absence of a cleavage plane between the tumor and the vascular bundle. Only 3 patients presented abnormalities in arterial signs, and these patients underwent complementary imaging tests to decide on the operative tactics.

En-bloc resection of the vessels affected by the tumor was indicated by the oncological surgeon on the basis of operative findings that the vessels presented conglomeration or adherence to the tumoral mass. The clamping and sectioning of the vessels was routinely performed as the last procedure in the en-bloc resection after freeing the whole tumor, with the aim of minimizing the duration of ischemia ${ }^{20}$. In 4 patients, this sequence could not be followed, and temporary shunts were used. In 2 patients, the common carotid and ipsilateral subclavian arteries were found to be simultaneously affected by neoplasia, and reconstructions were performed for both vessels. When performing vascular reconstructions, all the patients received endovenous heparin. The time range for the Cervical group operations was 5 to 16 hours, with a median of 8 hours, and a mean of 8.9 hours (standard deviation $=3.1$ ). In the Abdomen group, the time range varied from 7 to 16 hours, with a median of 10 and mean of 12.2 hours (standard deviation $=3.3$ ). For the Extremity group, operations had a time range of 6 to 11 hours, median of 8 , and mean of 8.1 hours (standard deviation of 1.7).

The clinical characteristics of the patients, the location of the primary tumor, the histological type, the vascular reconstructions, and the vascular substitutes are shown in Table 1.

The range of hospital stay periods for the Cervical group was 5 to 82 days, with a median of 11 days and mean of 18 (standard deviation $=19.9)$ days. In the Abdomen group, the range was 5 to 13 days with a median of 10 and mean of 9.5 days (standard deviation $=2.5$ ). The Extremity group presented with a range of hospital stay periods varying from 4 to 24 , median of 7 , and mean of 10 days (standard deviation $=6.4$ ) .

The follow-up was on an outpatient basis, with clinical examination and complementary imaging tests (duplex mapping or computerized tomography) performed twice during the first year and annually thereafter.

The probabilities of primary patency were obtained by means of the Kaplan-Meier technique, and comparative analysis between the curves was done by means of the logrank test, taking a significance level of $5 \%$.

\section{RESULTS}

There were 5 complications relating to the arterial grafts, of which 2 were early-stage and 3 were late-stage.

Among the early complications, 1 patient presented occlusion of the carotid graft during the immediate postoperative period, with a hemispheric cerebrovascular ischemic event and significant neurological sequelae. One patient presented rupture of the femoropopliteal graft on the $20^{\text {th }}$ day after the operation, consequent to infection and extensive necrosis of the operative wound. This patient had presented femoropopliteal obstruction prior to the operation, and despite ligation of the graft, there was no ischemia in the limb.

Among the late-stage complications, 1 patient presented symptomatic occlusion of the carotid graft 25 months after the operation, which was manifested by a transient ischemic episode (amaurosis fugax) without sequelae. This same patient simultaneously presented occlusion of the carotid-axillary graft, without ischemia in the upper limb. 
In another patient, there was a complication consisting of occlusion of the right branch of the aortobifemoral graft 48 months after the operation. This patient evolved with limiting intermittent claudication in 1 lower limb, and underwent cross-femoral grafting, which continues to function to the present day. Table 2 shows the arterial complications:

Two patients presented significant neurological deficits in limbs, consequent to combined resection of nerve seg- ments. One of these patients progressed to an inability to perform dorsiflexion of the foot, caused by resection of the fibular nerve, thus requiring an orthesis in order to be able to walk. The other patient progressed to present motor-sensory deficit in an upper limb, caused by resection of the roots of the brachial plexus, thus having to live with a dangling arm. Both of these patients had refused primary amputation as a treatment alternative, even though it had been predicted that such deficits might occur following the operation.

Table 1- Clinical characteristics, tumor location, histological type, vascular reconstruction, and vascular substitute.

\begin{tabular}{|c|c|c|c|c|c|}
\hline $\mathrm{P}$ & $\mathrm{G} / \mathrm{A}$ & Site & Histological type & Reconstruction & Substitute \\
\hline$\overline{1}$ & $\mathrm{M} / 54$ & Retroperitoneum (A) & Fibrohistiocytoma & Iliac-femoral & SV \\
\hline 2 & M / 27 & Testis (A) & Seminoma & Iliac-iliac & Dacron \\
\hline 3 & $\mathrm{M} / 57$ & Retroperitoneum (A) & Fibrosarcoma & Aortobiiliac & Dacron \\
\hline 4 & $\mathrm{M} / 51$ & Colon (A) & Adenocarcinoma & Iliac-femoral & SV \\
\hline 5 & $\mathrm{M} / 25$ & Testis (A) & Non-seminoma & Aorto-aortic & PTFE \\
\hline 6 & $\mathrm{M} / 52$ & Retroperitoneum (A) & Liposarcoma & Iliac-iliac & Dacron \\
\hline 7 & $\mathrm{~F} / 55$ & Retroperitoneum (A) & Leiomyosarcoma & Iliac-iliac & Dacron \\
\hline 8 & F / 29 & Retroperitoneum (A) & Fibrosarcoma & Aortobifemoral & Dacron \\
\hline 9 & $\mathrm{M} / 65$ & Retroperitoneum (A) & Liposarcoma & Aortobiiliac & Dacron \\
\hline 10 & F / 39 & Thigh soft tissue (E) & Liposarcoma & Femoropopliteal & SV \\
\hline 11 & $\mathrm{~F} / 49$ & Thigh soft tissue (E) & Leiomyosarcoma & Femoropopliteal & SV \\
\hline 12 & $\mathrm{~F} / 27$ & Thigh soft tissue (E) & Fibrohistiocytoma & Femoropopliteal & SV \\
\hline 13 & F / 39 & Thigh soft tissue (E) & Hemangiopericytoma & Femoropopliteal & SV \\
\hline 14 & $\mathrm{~F} / 15$ & Thigh soft tissue (E) & Synoviosarcoma & Femoropopliteal & SV \\
\hline 15 & $\mathrm{M} / 23$ & Thigh soft tissue (E) & Fibrosarcoma & Femoropopliteal & SV \\
\hline 16 & $\mathrm{~F} / 23$ & Thigh soft tissue (E) & Synoviosarcoma & Femoropopliteal & SV \\
\hline 17 & $\mathrm{~F} / 59$ & Skin $(E)$ & Malignant melanoma & Iliac-femoral & PTFE \\
\hline 18 & $\mathrm{~F} / 65$ & Skin $(\mathrm{E})$ & Malignant melanoma & Iliac-femoral & PTFE \\
\hline 19 & $\mathrm{~F} / 51$ & Colon (E) & Adenocarcinoma & Iliac-femoral & SV \\
\hline 20 & $\mathrm{M} / 24$ & Femur (E) & Osteosarcoma & Femoropopliteal & SV \\
\hline 21 & $\mathrm{~F} / 16$ & Fibula (E) & Osteosarcoma & Popliteal-posterior tibial & SV \\
\hline 22 & F / 62 & Fibula (E) & Synoviosarcoma & Popliteal-posterior tibial & SV \\
\hline 23 & $\mathrm{M} / 75$ & Tongue (C) & Spinocellular & Carotid-carotid & SV \\
\hline 24 & $\mathrm{M} / 54$ & Larynx (C) & Spinocellular & Carotid-carotid & SV \\
\hline 25 & $\mathrm{M} / 38$ & Tongue (C) & Spinocellular & Carotid-carotid & SV \\
\hline 26 & $\mathrm{M} / 46$ & Unknown (C) & Spinocellular & Carotid-carotid & SV \\
\hline 27 & $\mathrm{M} / 65$ & Larynx (C) & Spinocellular & Carotid-carotid & SV \\
\hline 28 & $\mathrm{M} / 54$ & Tongue $(\mathrm{C})$ & Spinocellular & Carotid-carotid & SV \\
\hline 29 & $\mathrm{M} / 61$ & Larynx (C) & Spinocellular & Carotid-carotid & SV \\
\hline 30 & $\mathrm{M} / 71$ & Tongue $(\mathrm{C})$ & Spinocellular & Carotid-carotid & SV \\
\hline 31 & M / 66 & Pharynx (C) & Spinocellular & Carotid-carotid + subclavian patch & $\mathrm{SV}+\mathrm{SV}$ \\
\hline 32 & $\mathrm{M} / 65$ & Skin $(\mathrm{C})$ & Basal cell carcinoma & Carotid-carotid + carotid-axillary & PTFE+PTFE \\
\hline 33 & $\mathrm{~F} / 79$ & Thyroid (C) & Anaplastic & Carotid-carotid & SV \\
\hline 34 & $\mathrm{M} / 60$ & Larynx (C) & Spinocellular & Carotid-carotid & SV \\
\hline 35 & $\mathrm{M} / 57$ & Unknown (C) & Spinocellular & Carotid-carotid & SV \\
\hline 36 & M / 69 & Pharynx (C) & Spinocellular & Carotid-carotid & SV \\
\hline
\end{tabular}

$\mathrm{P}=$ patient $\mathrm{G}=$ gender $\mathrm{A}=$ age

$\mathrm{M}=$ male $\mathrm{F}=$ female

$\mathrm{A}=$ Abdomen $\mathrm{E}=$ Extremity $\mathrm{C}=$ Cervical

$\mathrm{SV}=$ saphenous vein $\mathrm{PTFE}=$ expanded polytetrafluoroethylene prosthesis

Table 2 - Arterial complications

\begin{tabular}{|c|c|c|c|c|}
\hline GROUP & COMPLICATION & SUBSTITUTE & TIME & CLINICAL EVOLUTION \\
\hline Cervical & Occlusion & Saphenous vein & 1 day & Hemispheric cerebrovascular event \\
\hline $\begin{array}{l}\text { Cervical } \\
\text { upper limb }\end{array}$ & Occlusion (2) & PTFE (2) & 25 months & Amaurosis fugax + compensated \\
\hline Extremity & Rupture & Saphenous vein & 20 days & Compensated lower limb \\
\hline Abdomen & Occlusion of branch & Dacron & 48 months & Intermittent claudication \\
\hline
\end{tabular}


Among the other complications, 3 patients in the Cervical group and 3 in the Extremity group presented infections of the operative wound, which were treated by means of systemic antibiotic therapy. Two patients in the Cervical group and 3 in the Extremity group presented partial necrosis of the covering flap, which required debridement.

There were 2 amputations of limbs that were unrelated to failure of vascular reconstruction. One patient presented local recurrence of the tumor and underwent transfemoral amputation 11 months after the reconstruction. The patient who presented neurological deficit in the upper limb and , subsequently, occlusion of the carotid-axillary graft progressed with partial dehiscence of the flap and the opening of a salivary fistula, because of the constant pulling on the myocutaneous flap in the neck and supraclavicular fossa region caused by the hanging limb. Despite some attempts at corrective surgery, the fistula persisted, and this upper limb was amputated 51 months after the arterial reconstruction.

The estimated primary patency rates for the Cervical (carotid reconstructions), Extremity, and Abdomen groups, 2 and 5 years after the reconstruction, were $90 \%$ and $45 \%$, $91.3 \%$ and $91.3 \%$, and $100 \%$ and $60 \%$, respectively (Figure 1). There were no significant differences between the groups $(P=0.593)$.

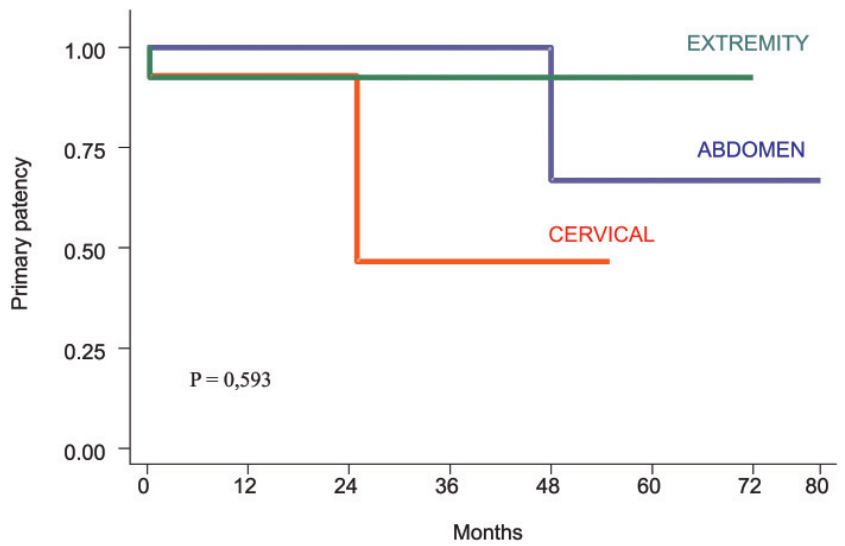

Figure 1.

The median length of follow-up for the Cervical, Abdomen, and Extremity groups was 11.5, 18, and 25 months, respectively. There were no deaths during the operation or during the hospital stay. All deaths that occurred resulted from progression of the neoplastic disease (11 Cervical, 8 Extremity, and 3 Abdomen patients).

\section{DISCUSSION}

From the analysis of the treatment of malignant neoplasias in cases in which the vascular bundle is affected, revascularization following arterial resection has played an important therapeutic role, a point which has been previously reported. For cases of cervical neoplasias, surgery in association with radiotherapy is the therapeutic option with the best possibility for locoregional control over the disease. ${ }^{22}$ For neoplasias in the extremities, ${ }^{23}$ the advances in operative technique that are associated with multidisciplinary therapy have meant that amputations, which until the 1970s were routinely performed, have been virtually discarded. Revascularization has enabled limb preservation with good limb function and with an obviously better quality of life. Regarding retroperitoneal sarcomas. ${ }^{24}$ which characteristically do not respond to radiotherapy and/or chemotherapy, the treatment result fundamentally depends on the possibility for complete resection of, and on the degree of the tumor malignancy.

In some cases in which there is firm adherence of the neoplasm to the vascular bundle, it is possible to perform the tumor resection by subadventitial dissection. With this technique, the blood flow is not interrupted, but the presence of microscopic tumor invasion into the vascular wall may still cause local recurrence of the disease..$^{25}$ There is also the additional risk of arterial rupture ${ }^{26}$ due to arterial wall erosion following tumor cell proliferation.

The best approach towards the resection of a tumor mass together with the vascular bundle is to immediately undertake arterial reconstruction. This is because, in addition to the loss of the axial vessel, a large part of the collateral must be sacrificed to ensure the oncological safety margins. Moreover, no preoperative tests are in current existence that can indicate with certainty whether the collateral circulation will be adequate in the event that only arterial resection and ligation of the stumps are performed.

The arterial substitutes used may be autologous ${ }^{3,27}$ or synthetic. ${ }^{4}$ In the abdominal region, ${ }^{9,14}$ prosthetic substitutes have been used more frequently because of better caliber compatibility and because of the high patency rates reported. In the present study, the patients in the Abdomen group mostly received prostheses. In contrast, in the cervical region ${ }^{1,28,29}$ and in the lower extremities, ${ }^{7,30}$ infectious complications leading to thrombosis and graft rupture were more associated with prosthetic substitutes. For these two groups, the long saphenous vein was the preferred substitute because of its greater biocompatibility and adequacy of caliber.

In the present study, 38 arterial reconstructions were performed in 36 patients, and there were 5 graft complications in 4 patients.

Analyzing the complications in each group, there was 1 complication among the 9 reconstructions performed in the Abdomen group. In the literature, complications relating to arterial grafts in this region have only infrequently been found. Among these, there have been cases of occlusion of a branch of an aortobifemoral graft, ${ }^{18}$ inguinal hematoma, ${ }^{9}$ and compartment syndrome in the lower limbs. ${ }^{18}$ 
In the Extremity group, there was 1 complication among the 13 reconstructions performed. In this region, the complications described have mostly been occlusions and infections. Early occlusions ${ }^{23,30}$ have frequently led to severe ischemia, culminating in amputation of the limb. Late-stage occlusions ${ }^{31}$ have been less common and presented few symptoms. Graft infection, ${ }^{7,30}$ with the need to ligate them, has also been the cause of severe ischemia and amputation of the limb.

In the Cervical group, there were 2 complications among the 14 carotid reconstructions, corresponding to a neurological morbidity rate of $14 \%$. The morbidity ${ }^{28}$ and mortality ${ }^{1}$ rates reported in the literature, resulting from graft failures in this region, have been as high as $30 \%$. In this region too, the most common complications have been occlusions and infections. Most of the early occlusions ${ }^{3,8,28}$ have been symptomatic, and hemispheric cerebral ischemia and its sequelae have been the predominant clinical consequence. Latestage occlusions ${ }^{29,32}$ have been less frequent and asymptomatic. Graft infection has caused rupturing, with massive hemorrhaging, ${ }^{28}$ thrombosis, ${ }^{1}$ and graft exposure. ${ }^{32}$

In the present study, comparative analysis between the groups did not show significant differences in primary patency. This was probably due to factors such as the absence of significant stenosis upstream from proximal anastomoses, absence of significant stenosis downstream from distal anastomoses, and also due to the use of vascular substitutes and appropriate operative techniques.
The present study shows that the surgical treatment of patients with malignant neoplasia affecting arteries is complex and a multidisciplinary therapeutic approach must be regarded as a priority. This was demonstrated by the long duration of the operations and the combined interventions by several specialized teams. In spite of this, there were no lengthy hospital stays, and mortality rates during the operation and hospital stay were zero. Among the arterial reconstructions, there were complications in 5 of the 38 procedures performed, with serious complications in only 1 patient (hemispheric cerebrovascular event with sequelae). No limbs were lost, and no deaths resulted from failure of the reconstructions. This leads us to believe that the presence of arterial invasion should not be a criterion for the tumor to be deemed as unresectable; consequently such patients should not be placed in the palliative-treatment only category.

\section{CONCLUSIONS}

1. Arterial reconstructions associated with resection of malignant tumors affecting arteries in the cervical, abdominal, or lower extremity segments can be performed with low morbidity-mortality rates.

2. There were no differences between primary patency rates of the performed arterial reconstructions regarding the groups studied.

\section{RESUMO}

Nishinari K, Wolosker N, Yazbek G, Zerati AE, Nishimoto IN, Puech-Leão P. Reconstruções arteriais associadas à ressecção de tumores malignos. Clinics. 2006;61(4):339-44.

OBJETIVO: Quando há acometimento de artérias tronculares por neoplasias malignas e o tratamento cirúrgico é empregado para realização de ressecções tumoral e arterial, a reconstrução vascular deve ser imediata, para evitar a isquemia de tecidos nobres. O objetivo desse trabalho é analisar os resultados do tratamento de pacientes portadores de neoplasias malignas submetidos a ressecções tumoral e vascular associada à reconstrução arterial, avaliando a perviedade primária das reconstruções, as complicações arteriais e a sobrevida dos pacientes.

MÉTODOS: Foram acompanhados 36 pacientes com neoplasias em regiões cervical, abdominal ou extremidades inferiores, operados eletivamente no período de setembro de 1997 a setembro de 2004 no Hospital do Câncer A.C.Camargo em São Paulo. Os pacientes foram divididos em três grupos de acordo com a localização das neoplasias:
Cervical (14), Extremidade (13) e Abdome (9). Foram realizadas 38 reconstruções arteriais nos 36 pacientes.

RESULTADOS: Houve cinco complicações arteriais, sendo duas precoces e três tardias. Entre as precoces, houve uma oclusão carotídea sintomática com seqüelas e uma rotura de enxerto femoral sem seqüelas. Entre as tardias, houve uma oclusão carotídea sintomática, uma oclusão de enxerto carotídeo-axilar e uma oclusão de ramo de enxerto aortobifemoral, todas sem sequelas. Não houve diferença entre os índices de perviedade arterial primária . Todos os óbitos (22) ocorreram devido à evolução da doença neoplásica.

CONCLUSÕES: As reconstruções arteriais associadas à ressecção de neoplasias malignas em segmentos cervical, abdominal ou extremidades inferiores podem ser realizadas com baixos índices de morbi-mortalidade. Não houve diferença entre os índices de perviedade primária das reconstruções.

UNITERMOS: Neoplasia Maligna, Ressecção Vascular, Reconstrução Arterial, Enxerto Arterial, Prótese Vascular. 
1. Conley JJ. Free autogenous vein graft to the internal and common carotid arteries in the treatment of tumors of the neck. Ann Surg. 1953; 137:205-14.

2. Debakey ME, Creech O Jr, Cooley DA. Occlusive disease of the aorta and its treatment by resection and homograft replacement. Ann Surg. 1954;140:290-310.

3. McCready RA, Miller SK, Hamaker RC, Singer MI, Herod GT. What is the role of carotid arterial resection in the management of advanced cervical cancer? J Vasc Surg. 1989;10:274-80.

4. Fadel E, Chapelier A, Bacha E, Leroy-Ladurie F, Cerrina J, Macchiarini $\mathrm{P}$, et al. Subclavian artery resection and reconstruction for thoracic inlet cancers. J Vasc Surg. 1999;29:581-8.

5. Bower TC, Nagorney DM, Cherry Jr KJ, Toomey BJ, Hallett JW, Panneton JM, et al. Replacement of the inferior vena cava for malignancy; an update. J Vasc Surg. 2000;31:270-81.

6. Nishinari K, Wolosker N, Yazbek G, Zerati AE, Nishimoto IN, Penna V, et al. Vascular reconstruction in limbs with malignant tumors. Vasc Endovsc Surg. 2004;38:423-9.

7. Nambisan RN, Karakousis CP. Vascular reconstruction for limb salvage in soft tissue sarcomas. Surgery. 1987;101:668-77.

8. Biller HF, Urken M, Lawson W, Haimov M. Carotid artery resection and bypass for neck carcinoma. Laryngoscope. 1988;98:181-3.

9. Kelly R, Skinner D, Yellin AE, Weaver FA. En bloc aortic resection for bulky metastatic germ cell tumors. J Urol. 1995;153:1849-51.

10. Meleca RJ, Marks SC. Carotid artery resection for cancer of the head and neck. Arch Otolaryngol Head Neck Surg. 1994;120:974-8.

11. Nishinari K, Wolosker N, Yazbek G, Malavolta LC, Zerati AE, Kowalski LP. Carotid reconstruction in patients operated for malignant head and neck neoplasia. Sao Paulo Med J. 2002;120:137-40.

12. Karakousis CP, Karmpaliotis C, Driscoll DL. Major vessel resection during limb-preserving surgery for soft tissue sarcomas. World J Surg. 1996;20:345-50.

13. Schwarzbach MHM, Hormann Y, Hinz U, Bernd L, Willeke F, Mechtersheimer G, et al. Results of limb-sparing surgery with vascular replacement for soft tissue sarcoma in the lower extremity. J Vasc Surg. 2005;42:88-97.

14. Beck SD, Foster RS, Bihrle R, Koch MO, Wahle GR, Donohue JP. Aortic replacement during post-chemotherapy retroperitoneal lymph node dissection. J Urol. 2001;165:1517-20.

15. Unlu Y, Tekin SB, Ceviz M, Balci A. A successful right axillary artery graft to repair a ruptured axillary artery due to the involvement of lymphoma: report of a case. Surg Today. 2003;33:72-4.

16. Bianchi C, Ballard JL, Bergan JH, Killeen JD. Vascular reconstruction and major resection for malignancy. Arch Surg. 1999;134:851-5.
17. Carrel T, Berdat P, Schmidli J. Cardiovascular interventions during oncologic surgery: technical principles and mid-term survival. Vasa. 2000;29:133-7.

18. DiPerna CA, Bowdish ME, Weaver FA, Bremner RM, Jabbour N, Skinner D, et al. Concomitant vascular procedures for malignancies with vascular invasion. Arch Surg. 2002;137:901-7.

19 Wolosker N, Nakano L, Rosoky RA, Munia MA, Muraco-Netto, B Puech-Leão P. Endovascular treatment for intermittent claudication in patients who do not improve with clinical treatment. Clinics. 2005;60:193-200.

20 Nishinari K, Wolosker N. Regarding "Floppy aortic graft reconstruction for germ cell tumor invasion of the infrarenal aorta". J Vasc Surg. 2004;39:922

21 Snyderman CH, D’Amico F. Outcome of carotid artery resection for neoplastic disease: a meta-analysis. Am J Otolaryngol. 1992;13:37380.

22 Hohenberger P, Allenberg JR, Schlag PM, Reichardt P. Results of surgery and multimodal therapy for patients with soft tissue sarcoma invading to vascular structures. Cancer. 1999;85:396-408

23 Bevilacqua RG, Rogatko A, Hajdu SI, Brennan MF. Prognostic factors in primary retroperitoneal soft-tissue sarcomas. Arch Surg. 1991;126:328-34

24 Kennedy JT, Krause CJ, Loevy S. The importance of tumor attachment to the carotid artery. Arch Otolaryngol. 1977;103:70-3

25 Jaeger N, Weissbach L, Hartlapp JH, Vahlensieck W. Risk/benefit of treating retroperitoneal teratoid bulky tumors. Urology. 1989;34:14-7

26 Nishinari K, Wolosker N, Yazbek G, Malavolta LC, Zerati AE, Penna V, et al. Vascular reconstruction in limbs associated with resection of tumors. Ann Vasc Surg. 2003;17:411-6.

27 East CA, Adiseshiah M, Grant HR. Resection of the extra cranial carotid artery in head and neck cancer. J Otolaryngol .1989;18:298-302.

28 Wright JG, Nicholson R, Schüller DE, Smead WL. Resection of the internal carotid artery and replacement with greater saphenous vein: a safe procedure for en bloc cancer resections with carotid involvement. J Vasc Surg. 1996;23:775-80.

29 Kawai A, Hashizume H, Inoue H, Uchida H, Sano S. Vascular reconstruction in limb salvage operations for soft tissue tumors of the extremities. Clin Orthop Relat Res. 1996;332:215-22.

30 Matsushita M, Kuzuya A, Mano N, Nishikimi N, Sakurai T, Nimura Y, et al. Sequelae after limb-sparing surgery with major vascular resection for tumor of the lower extremity. J Vasc Surg. 2001;33:694-9.

31 Sessa CN, Morasch MD, Berguer R, Kline RA, Jacobs JR, Arden RL. Carotid resection and replacement with autogenous arterial graft during operation for neck malignancy. Ann Vasc Surg. 1998;12:229-35. 